\title{
Development of the Apparatus for Measuring the Throwing Power of an Electrodeposition \\ Coating Solution.
}

\author{
Nobuo Furuno*, Tomosaburo Kawahara* \\ and Yoshiaki ÔYABU
}

Nippon Paint Co., Ltd.

\begin{abstract}
From the investigation of the electrodeposition coating mechanism occuring in the enclosed system such as the inside surface of a steel pipe, authors have reported previously that the throwing power $T h$ determined by a pipe test is caluculated in accordance with next

$$
T h^{2}=(a / L) \sigma \cdot E(S / I)
$$

Authors have developed the apparatus for calculating, indicating and recording automatically $T h$ with this formula. In order to measure the throwing power $T h$ of an electrodeposition coating solution by this apparatus, at first, the $a / L$ is set up to the predetermined constant which is decided by the pipe dimension. Secondly, the specific conductivity $\sigma$ of the coating solution, the applied voltage $E$, and the surface area $S$ of the anode are measured and these values are set up on the dial of this apparatus. Finally, the current $I$ through the anode which has an approximately uniform current density is inducted as the only input signal which varies with the time. Then, this apparutus gives the chart on which the throwing power $T h$ is shown versus electrodeposition time $t$.

Comparing Th-t curves with Several applied Voltage processes, it became clear that Th-t curves are not so more influenced for the zinc phosphate treatment steel panel than the untreatment one.
\end{abstract}

* 246, Ikeda, Neyagawa, Osaka, Japan 


\section{電着塗装液のつきまわり性 測定記録装置の開発}

古野 伸 * $^{*}$ 河原友三郎* ・大藪 権 昭*

要 旨

われわれは鋼管内面のように封じられた系内での電着機構の研究の結果, パイプテスト によるつきまわり性 $T h$ は次式の計算で求められることを報告した1)。

$$
T h^{2}=\frac{a}{L} \cdot \frac{\sigma \cdot E \cdot S}{I}
$$

この式を使って塗装電流を直ちに自動的に演算し，Thを指示し記録する装置を開発した。

$T h$ を測定するにはまず $a / L$ をあらかじめ定数として設定する。次に塗装液の比電導 度 $\sigma$, 印加電圧 $E$, そして均一な電流密度とみなせる陽極表面積 $S$ を測定してダイヤル にあらかじめ設定して执き, 電着叙装開始後の陽極に流れる電流を入力信号として, この 装置に与兄る。その結果, 時間 $t$ 亿対するThを示す記録グラフが得られる。

リン酸亜鉛皮膜化成処理のつきまわり性に及ぼす効果について，この装置を使って二， 三の実験を行なった結果，一般に電圧の印加方法によってTh は影響されるがリン酸亜鉛 皮膜処理することによって, 電圧の印加方法の影響の少ない $T h-t$ 曲線が得られること がわかった。

\section{1. 緒言}

電着塗装の特長の一つはすぐれたつきまわり性にあ る。このつきまわり性の評価尺度は従来色々と工夫され て怙り，それぞれに応じて評価の測定方法が紹介されて いる。しかしこれらの評価值はいずれも所定の通電時間 後の值を表わするので, 評価值と通電時間との関係を求 めるには遂次的に多くの測定を必要とした。著者らは先 飞鋼管内面の電着塗装機構を解析し, つきまわり性 $T h$ 飞ついて報告した11)。つきまわり性について，実用的面 から検討してみると，電着時間に対するTh の大きさ， 扣よび測定条件特に直流供給電源容量や陽極材質の問題 飞注意すべきことがあることに気がついた。とこで本装 置を開発し、これらのことを明らかにすることにした。

\section{2. つきまわり性測定記録装置の設計}

\section{1 測定方法の原理}

鋼製パイプの内面に塗装される長さ $T h$ をつきまわり

昭和 47.4 .10 受理

*日本ペイント株式会社中央研究所 大阪府寝屋川市池田中 246
性の尺度とする場合は次の関係式が成立する1)。

$$
T h^{2}=a / L \cdot R / \rho=a / L \cdot \sigma \cdot E \cdot S / I
$$

ここに $a\left(\mathrm{~cm}^{2}\right)$ : 鋼管の（電力線の侵入する）断面積 $L(\mathrm{~cm})$ : 鋼管入口の内面のまわりの長さ

$\sigma\left(\Omega^{-1} \cdot \mathrm{cm}^{-1}\right):$ 塗装液の比電導度

$$
R\left(\Omega \cdot \mathrm{cm}^{2}\right): R=E / i, \quad R=E \cdot S / I
$$

$E(\mathrm{~V}):$ 印加電压

$S\left(\mathrm{~cm}^{2}\right)$ ：鋼管とは別に設置された，均一な電 流密度 $(i=I / S)$ の期待できる陽極の 表面積

$I(\mathrm{~A})$ : 鋼管内面の塗装面の長さが $T h$ にな ったとき，上記陽極に流れる電流

この式を利用して Th と通電時間 $t$ ( $I$ は時間 $t$ の関 数）との関係を自動的に記録する装置を開発した。

\section{2 演算方法の原理}

式(1)の両辺の対数をとって,

$$
2 \log T h=\log (a / L \cdot \sigma \cdot E \cdot S)-\log I
$$

式 $(2)$ に持いて右辺第 1 項は電着塗装液, 電着条件, 電 極構成に基づく定数で電着時間依存しない。第 2 項の $I$ は電着時間㳖存するから, 電着時間沁じて変化す るIを入力としてTh 演算する演算回路を組めばよい 


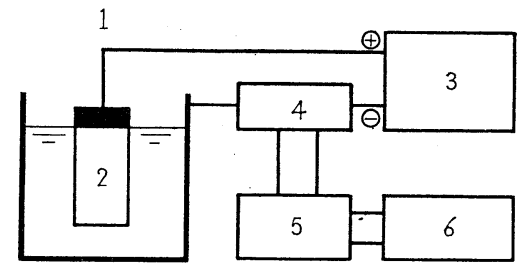

Fig. 1. Block diagram of the recording apparatus, Which measures the $T h$
1. Electrodeposition coating vessel
2. Test panel
3. D. C. source
4. Shunt
5. Operational circuit
6. Recorder

ことになる。この電気回路には, 演算増幅器（オペレー ショナル・アンプ）で構成したアナログ演算方式を採用 した。

\section{3 測定装置の構成}

この装置の回路構成を図-1 に示す。

2.3.1 電着槽と電極 陽極はその表面積 $S$ が測定で きる形状で，しかもそこに流れる電流密度が均一である ことが望ましい。一方陰極はその生成物による極間抵抗 に及ぼす影響が無視できるように陽極に比べて大きいこ とが望ましい。以上の要求を満たすものとして次のよう な電着槽と電極が考兄られる。必要に応じて使いわけす ればよい。

（1）裏面を絶縁した二つの平板を平行に配置し，そ れぞれ陽極と陰極にする。

（2）陰極を兼ねた円筒容器の中央に円柱を配置し， これを陽極とする2)。この直径は陰極の直径の半 分程度以下の大きさで，この底面を絶緑すること が望ましい。

（3）陰極を兼放た円筒容器の中央に平板を配置し, これを陽極とする。この幅は陰極の直径の半分程 度以下の大きさで，角の部分を絶縁することが望 ましい。

2.3.2 電源 自動定電流定電圧電源（高砂製作所 $\mathrm{G} \cdot \mathrm{P}$ タイプ）用いた2)。最大出力電圧 $500 \mathrm{~V}$ ，電流 5 A, 安定精度 $0.05 \%+10 \mathrm{mV}$, 応答速度 $20 \mathrm{~m} \mathrm{sec}$ 以内, 定電流から定電圧への切換が自動的に行なわれ，この定 電流となる電流の設定を任意に変えられる特徵をるつ。

\section{3 .3 分流器 抵抗值 $1 \Omega^{ \pm} 1 \times 10^{-4} \Omega(5 \mathrm{~W})$}

2.3.4 演算回路 演算回路は式 $(2)$ 亿基づくアナロ グ演算から成る。右辺第 1 項 $\log (a / L \cdot \sigma \cdot E \cdot S)$ 飞対応する 電圧は通電時間とともに変わらないるのとみなして, $a / L$ をあらかじめ設定し， $\sigma \cdot E \cdot S$ を測定し，これらの積特 よび対数值を求めてバイアス電圧として設定する。右辺
Table 1. Specification of the logarithmic convertor

\begin{tabular}{l|c|c}
\hline Measuring range & $5 \mathrm{~V}$ & $50 \mathrm{~V}$ \\
\hline Ratio of division & 1 & $1 / 10$ \\
Input voltage & $0.5 \mathrm{mV} \sim 5 \mathrm{~V}$ & $5 \mathrm{mV} \sim 50 \mathrm{~V}$ \\
Input impedance & $10 \mathrm{k} \Omega$ & $100 \mathrm{k} \Omega$ \\
\hline Output voltage & \multicolumn{2}{|c}{$0 \sim 10 \mathrm{mV}$} \\
Output impedance & \multicolumn{2}{|c}{$10 \Omega$} \\
Response & $20 \mathrm{~dB} / 0.5 \mathrm{sec}$ \\
\hline
\end{tabular}

第 2 項 $\log I$ 飞対応する電圧は電流 $I$ 飞比例する分流器 からの信号電圧を対数增幅器を用いて，通電時間に対し て連続的に变化する值として得た。ここで使用した対数 増幅器の性能を表-1 示す。

増幅器の入力電压 $V_{\text {in }}$ と出力電圧 $V_{\text {out }}$ との間に次 の関係が存在する。

$$
V_{\text {out }}(\mathrm{mV})=8.2525+2.5 \log f \cdot V_{\text {in }}(\mathrm{V})
$$

式 $(1)$ を変形して電流 $I$ を求める。(このときの分圧比 率を $f$ とする)

$$
I=1 / T h^{2} \cdot a / L \cdot E \cdot S \cdot \sigma
$$

この電流に比例する出力電圧は分流器の抵抗を $R_{S}$ とす ると,

$$
V_{\mathrm{in}}=I R_{S}=1 / T h^{2} \cdot a / L \cdot E \cdot S \cdot \sigma \cdot R_{S}
$$

この值を式(3)の $V_{\text {in }}$ 亿代入する。

$$
\begin{aligned}
V_{\text {out }}= & 8.2525+2.5 \log \\
& \left(1 / T h^{2} \cdot a / L \cdot E \cdot S \cdot \sigma \cdot R_{S} \cdot f\right)
\end{aligned}
$$

この出力電圧に式 $(2)$ 右辺第 1 項の値をバイアス電圧 $V_{k}(\mathrm{mV})$ として順方向 $\left(V_{k}\right.$ の符号が負となれば逆方 向を意味する。に加光る。したがって図-1 の回路で記 録される電圧 $V_{R}(\mathrm{mV})$ は,

$$
\begin{aligned}
V_{R}= & 8.2525+2.5 \mathrm{log} \\
& \left(1 / T h^{2} \cdot a / L \cdot E \cdot S \cdot \sigma \cdot R_{S} \cdot f\right)+V_{k}
\end{aligned}
$$

となる。

2.3.5 記録計と記録紙の目盛特よびバイアス電圧決 定法たと兊ば, 直径 $1.75 \mathrm{~cm}$ の鋼管湢 $1.60 \mathrm{~cm}$ 厚 さ $0.03 \mathrm{~cm}$ の鋼板を入れたパイプテスト法による測定值 に対応する值を示すには，比例定数 $a / L$ を $\pi(1.75 / 2)^{2} /$ $\{\pi \times 1.75+2(1.60+0.03)\}=0.275(\mathrm{~cm})$ とする。この 尺度での Th の最大值を $30(\mathrm{~cm})$, 最小值をこの $1 / 10$ の $3 \mathrm{~cm}$ とする装置について報告する。Th $(3 \sim 30 \mathrm{~cm})$ の変化幅は $20 \mathrm{~dB}$, したがって $2 \log T h$ は $40 \mathrm{~dB}$ とな る。したがって, 式から $\log I$ の変化の記録範囲は, 40 $\mathrm{dB}$ 注相当することがわかる。対数増幅器の出力は, 入 力変化 $80 \mathrm{~dB}$ に対して $10 \mathrm{mV}$ であるから $40 \mathrm{~dB}$ に対し ては $5 \mathrm{mV}$ となる。 $T h=3 \mathrm{~cm}$ のとき, 出力 $5 \mathrm{mV}(T h$ 
が $30 \mathrm{~cm}$ のとき，出力 $0 \mathrm{mV}$ ) となるように決めると記 録計はフルスパン $5 \mathrm{mV}$ （全目盛長または，記録紙幅は $25 \mathrm{~cm}$ ）レンジを使用し，記録紙は $0 \sim 5 \mathrm{mV} 25 \mathrm{~cm}$ を対 数目盛で $30 \sim 3 \mathrm{~cm}$ に目盛ったものを使用する。したが って式（7）飞 $a / L=0.275, T h=3 \mathrm{~cm}$ を代入し, 得ら れる電圧 $V_{R}$ が $5 \mathrm{mV}$ となるように $V_{k}$ が決められる。 $5=8.2525+2.5 \log \left(1 / 9 \times 0.275 \cdot E \cdot S \cdot \sigma \cdot R_{S} \cdot f\right)+V_{k}$

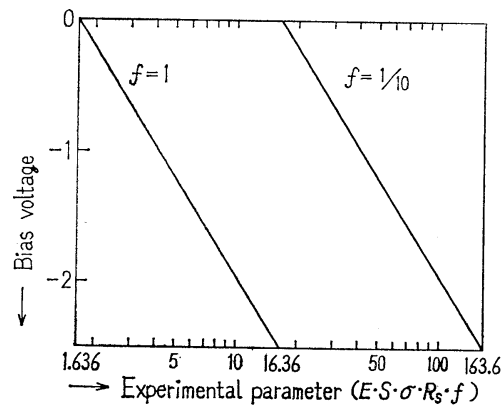

Fig. 2. Relationship between a bias voltage and an experimental parameter

$E$ : Applied voltage (V)

$S:$ Anode area $\left(\mathrm{cm}^{2}\right)$

$\sigma$ : Specific conductivity of the coating solution $(\sigma / \mathrm{cm})$

$R_{S}:$ Resistance of the shunt $(\Omega)$

$f$ : The ratio of division

Table 2. Relationship between the current and the output voltage $V_{R}(0$ or $5 \mathrm{mV})$ of this apparatus

\begin{tabular}{c|c|c|c}
\hline \multirow{2}{*}{$\begin{array}{c}\text { Experimental } \\
\text { parameter }\end{array}$} & $\begin{array}{c}\text { Bias } \\
\text { voltage }\end{array}$ & \multicolumn{2}{|c}{ Current (mA) } \\
\cline { 3 - 4 }$(\mathrm{V} \cdot \mathrm{cm})$ & $(\mathrm{mV})$ & $\begin{array}{c}V_{R}=0 \mathrm{mV} \\
(T h=3 \mathrm{~cm})\end{array}$ & $\begin{array}{c}V_{R}=5 \mathrm{mV} \\
(T h=30 \mathrm{~cm})\end{array}$ \\
\hline 1,636 & -7.500 & $*(9.49 \mathrm{~cm})$ & 500 \\
1,000 & -6.965 & $*(7.42 \mathrm{~cm})$ & 305.5 \\
\cline { 3 - 4 } 163.6 & -5.000 & 5,000 & 50 \\
100.0 & -4.465 & 3,055 & 30.55 \\
16.36 & -2.500 & 500 & 5 \\
10.00 & -1.965 & 305.5 & 3.055 \\
1.636 & 0 & 50 & 0.5 \\
1.000 & +0.535 & 30.55 & $* *(23.5 \mathrm{~cm})$ \\
0.1636 & +2.500 & 5 & $* *(8.67 \mathrm{~cm})$ \\
\hline
\end{tabular}

Experimental parameter : $\left(E \cdot S \cdot \sigma \cdot R_{S} \cdot f\right)$

* The value of $T h$ at current $I=5 \mathrm{~A}$

(5A : The maximum current of the D. C. source)

** The value of $T h$ at current $I=0.5 \mathrm{~mA}$

(The resistance of the shunt is $1 \Omega$ ) $0.5 \mathrm{~mA} \rightarrow$ $0.5 \mathrm{mV} \quad 0.5 \mathrm{mV}$ : the input voltage which the output voltage of the $\log$ converter is $0 \mathrm{mV}$

$$
\therefore \quad V_{k}=0.5350-2.5 \log \cdot E \cdot S \cdot \sigma \cdot R_{S} \cdot f
$$

この式を図示すると図-2 となる。電着塗装液の比電畹 度 $\sigma$ を測定し，印加電圧 $E$ を決定し，陽極表面積 $S$ を求 め分流器の抵抗 $R_{S}$, 分圧比率 $f$ を適正に選べば式 (8) または図 -2 からパイアス電圧 $V k$ が求められる。 六イ アス電圧は直流安定化電源を使用し，この電源から抵 抗で分圧した $0 \sim 2.5 \mathrm{mV}$ の電圧 $\left(E \cdot S \cdot \sigma \cdot R_{S} \cdot f\right.$ の值で 1. $636 \sim 16.36$ に相当）を10回転バリオームで分割して 任意の電圧を得られるようにした。

\section{4 演算性能}

種々の条件について出力電圧 $V_{R}$ が $0 \mathrm{mV}$ と $5 \mathrm{mV}$ を 示す, 電流 $I$ 拈よびバイアス電圧 $V k$ の值を表-2 に示 す。表-2 の太線にて囲った条件について出力電圧 $V_{R}$ を実測し，0.5\% 以内の精度で一致することを確かめ た。これとは別に記録計, 対数増幅器の直線性について それぞれ $0.3 \% ， 0.5 \%$ 以内であることを確認した。

対数変換器の応答時間は $20 \mathrm{~dB} / 0.5 \mathrm{sec}$ であるので電 着実験の初期の変化の測定記録に特いてはいくらかの遅 れを生じるが，この程度の遅れは実用的には全く支障が ない。

\section{3. 本装置による $\boldsymbol{T h}$ 測定例とその考察}

\section{1 Th の電着時間依存性}

実験と結果使用した塗装液はマレイン化油をトリ エチルアミンで一部中和し, 脱イオン水に分散し, 不揮

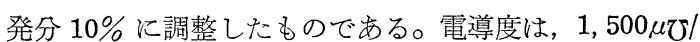
$\mathrm{cm}\left(30^{\circ} \mathrm{C}\right)$ であった。内径 $10.5 \mathrm{~cm}$, 深さ $12.5 \mathrm{~cm}$ の ステンレススチール製円筒容器を，陰極を兼ねた電着槽 とした。中央に厚さ $0.5 \mathrm{~mm}$, 幅 $5 \mathrm{~cm}$, 長さ $15 \mathrm{~cm}$ の 鋼板をつるし，長さ $10 \mathrm{~cm}$ を残し上部を絶縁テープでシ ールして塗装液に浸したものを陽極とした。（表面積は

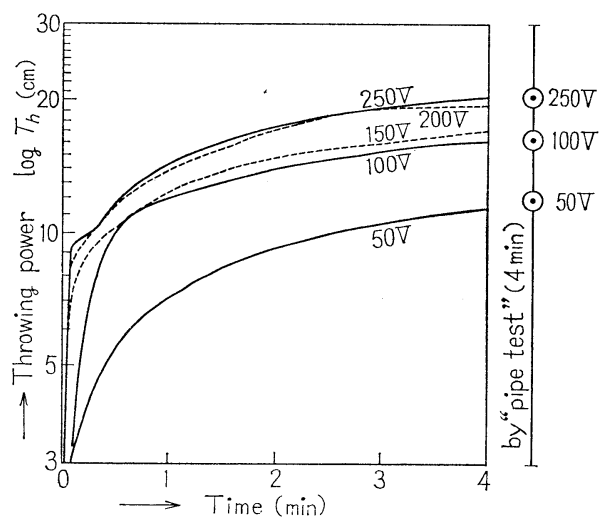

Fig. 3. Th $-t$ curves and the values of $T h$ measured by the "pipe test" 


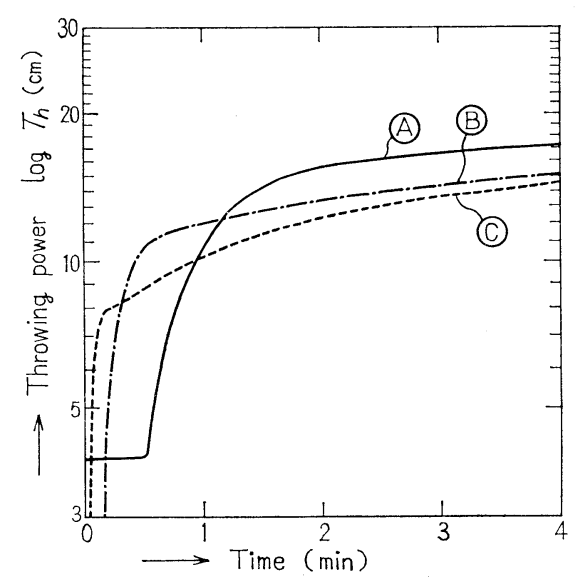

Fig. 4. $T h-t$ curves

applied voltage : $100 \mathrm{~V}$

test panel : untreatment steel panel presetting maximum current Which is determined by the D. C. Source

$$
(\mathrm{A}: 0.5 \mathrm{~A}, \mathrm{~B}: 1 \mathrm{~A}, \mathrm{C}: 5 \mathrm{~A})
$$

角の部分を無視して $100 \mathrm{~cm}^{2}$ となる）

印加電圧 $50 ， 100 ， 150 ， 200 ， 250 \mathrm{~V}$ で本装置を使用 して，Thを 4 分間測定した結果を図-3 に示す。式 (1) の $a / L=0.275$ となるパイプテストとして, 長さ $30 \mathrm{~cm}$ 直径 $1.75 \mathrm{~cm}$ の鋼管内に幅 $1.60 \mathrm{~cm}$ 厚さ $0.03 \mathrm{~cm}$ の鋼 板を入れたるのを陽極として 4 分間電着塗装し, 鋼板上 に得られた塗面の長さを測定した。この結果を図-3の 右側に記す。

$\left(a=\pi \cdot(1.75 / 2)^{2}, \quad L=\pi \times 1.75+(1.60+0.03) \times 2\right.$,

$a / L=0.275$ となる)

この実測に和いて，次のことに注意した。

1. 液温の管理を厳重にした。またパイプテストの鋼 管の外面をあらかじめ絶縁し，余分な電着を行なわ ず通電による温度上昇と塗装液の変化をさけた。

2. パイプ内はかきまぜられないから，両者ともかき まぜなかった。

3. 陽極となる鋼管および, 鋼板ともよく脱脂洗浄し た。

4. 塗装用電源は, 容量が $5 \mathrm{~A}$ と比較的大きく, 初期 の定電流となる時間は数秒しかないので, ほぼ理想 的に定電圧電着が行なわれた。したがって，Thの 測定とパイプテスト実施に括いて, 同一の条件で電 着したとみなせる。

考察本装置により, 図-4 のような Th の時間変 化が一目りょら然のグラフが得られ, 通電時間に対して $T h$ の連続記録測定が可能になった。

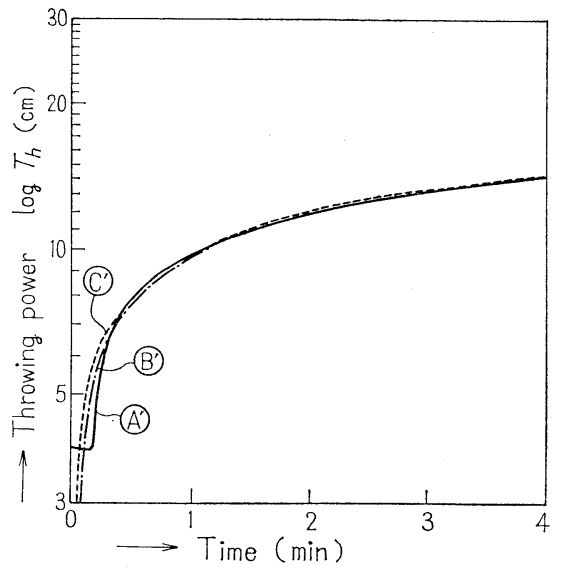

Fig. 5. Th- $t$ curves

applied voltage : $100 \mathrm{~V}$

test panel: zinc phosphate treatment steel panel presetting maximum current Which is determined by the D. C. Source

$\left(\mathrm{A}^{\prime}: 0.5 \mathrm{~A}, \mathrm{~B}^{\prime}: 1 \mathrm{~A}, \mathrm{C}^{\prime}: 5 \mathrm{~A}\right)$

このように Th の時間変化が記録測定されることによ $っ \tau$,

1. 目的とする $T h$ に至る通電時間を容易に求めるこ とができる。たとえば $T h=15 \mathrm{~cm}$ に至る通電時間 は印加電圧が $200 \sim 250 \mathrm{~V}$ の場合 $70 \sim 80$ 秒, 150 $\mathrm{V}$ で 130 秒，そして $100 \mathrm{~V}$ では 180 秒であることが わかる。

2. 絶対值だけでなく時間変化の好ましいパターンの 電着条件を求めることができる。たとえば，印加電 圧が $50 \mathrm{~V}$ では Th の増加速度が $100 \mathrm{~V}$ の場合に比 ベてかなり悪い。短い時間で高いThに至り，その 後は Thが変化しないタイプが最も好ましいと考光 ると $100 \mathrm{~V}$ の場合の方がこのタイプに近い。

本装置の測定值がパイプテストの測定值とよく一致し たので，式（1）の演算をらまくできたことが証明され た。（式（1）を使っての計算値とパイプテスト測定値の 一致する範囲については先に報告した1)。）

\subsection{Th の電圧昇圧法依存性}

許容される電流值の小さい電源を使って大きな被塗物 を電着するとき, 通電初期は, 電源の許容最大電流しか 流さないように, 順次電圧をあげて, 所定の電圧に至ら せる昇圧方法がとられることがある。本装置を使用して このような昇圧方法がつきまわり性に与光る影響を調べ る。

実験と結果 出力電圧を $100 \mathrm{~V}$ に設定し, 出力最大 電流を (A) $0,5 \mathrm{~A}$ ，(B) $1 \mathrm{~A}$ ，(C) $5 \mathrm{~A}$ と 3 通りに設定する。す なわち, この電源を使って電着すると, 電着板と㓌極と 
の極間抵抗の小さいときは，それぞれ設定した最大電流 を流すに必要な電压が印加され，塗膜形成とともに電圧 は設定電圧 $100 \mathrm{~V}$ まで自動的に増加する。塗装液は前実 験と同じである。被塗物の試験板として摩鋼板を使用し た結果を図ー4, リン酸业鉛皮膜処理板を使用した結果を 図-5 に示す。

考察昇圧方法が变わればつきまわり性の時間変化 がこのように異なることがわかった。塗装時間が十分あ るなら，徐々に昇圧ないしは初期は定電流電着を行なら 通電法の方がつきまわり性にとって有利であることがわ かる。しかしながら，複雑な形状の物体を塗装する場 合，陰極からの距離の大小によってもこのような差異が
生じると予測されるので，全体の均一性についてみれば このような差異の生じる塗料は好ましくない。

図-4 に比較して図-5 を比較して見ると，リン酸亜鉛 皮膜処理すると先に述べた通電方法による差異がほとん どなくなっている。すなわち，この試料塗装液は摩鋼板 よりもリン酸亜鉛皮膜処理鋼板に塗装する方が，好まし い結果を与えている。

（本報告は昭和 46 年 11 月 18 日, 色材研究発表会で発 表した。)

$$
\text { 文献 }
$$

1）古野, 川井, 大藪, 色材, 42, 362 (1969)

2) 古野, 大藪, 色材, 44, 359 (1971)

報文

色 材 協 会 誌 Vol. 45 No. 10 (予告)

塗膜の顕徵鏡的研究（第 1 報）

エッジ部に和ける膜厚

大日本塗料(株) 道 野 鶴 松”他

電着塗膜形成機構の考察（II）

印加電生走査法に拈ける電流-電圧曲線の解析 日本ペイント(株) 古野 伸夫他

テーマ資料 (エマルションと色材工学)

エマルションの生成とその安定性

東京理科大 北 原 文 雄

エマルション塗料の防腐対策. 関西ペイント(株) 松 崎 重 夫

水系化粧品と顔料 (株) 資生堂研究所 奈 良 道子他

界面活性剂と色材工学 ·花王石䲓(株) 竹 内 節 他

\section{色材サロン}

夏季ゼミナールに参加して 長島特殊塗料(株) 木 下 啓 吾

文献

特許 公告

\section{予定行事}

来る 11 月 8 日, 日本化学会講堂にて 1972 年度色材研究発表会, 懇親会, 9 日は見学会を予定していま す。詳細は10月号に揭載いたします。 